\title{
Evaluating the Effect of the rs2229238 and the rs4845625 Interleukin 6 Receptor Gene Polymorphisms on Body Mass Index and the Risk of Type 2 Diabetes in an Iranian Study Population
}

\author{
Hamid Reza Galavi, ${ }^{1}$ Ramin Saravani, ${ }^{2,}{ }^{*}$ Ali Reza Alamdari, ${ }^{2}$ Nasrin Ranjbar, ${ }^{2}$ Elhame Damani, ${ }^{3}$ and \\ Tooba Nakhzari Khodakhier ${ }^{4}$ \\ ${ }^{1}$ Student Scientific Research Center, Department of Clinical Biochemistry, School of Medicine, Zahedan University of Medical Sciences, Zahedan, IR Iran \\ ${ }^{2}$ Cellular and Molecular Research Center, Department of Clinical Biochemistry, School of Medicine, Zahedan University of Medical Sciences, Zahedan, IR Iran \\ ${ }^{3}$ Department of Health Education and Promotion, School of Public Health, Zahedan University of Medical Sciences, Zahedan, IR Iran \\ ${ }^{4}$ Department of Biology, Sistan and Balochestan Unviersity, Sistan and Balochestan, IR Iran \\ "Corresponding author: Ramin Saravani, Cellular and Molecular Research Center, Department of Clinical Biochemistry, School of Medicine, Zahedan University of Medical \\ Sciences, Zahedan, IR Iran. Tel: +98-543329892, Fax: +98-543329892, E-mail: saravaniramin@yahoo.com
}

Received 2015 September 22; Revised 2016 January 04; Accepted 2016 January 12.

\begin{abstract}
Background: Type 2 diabetes (T2D) is an inflammatory disease that may cause inflammatory responses if it is not controlled; and may also lead to clinical manifestations such as retinopathy, nephropathy, and neuropathy. Interleukin 6(IL6) is an important proinflammatory cytokine that controls the influence of systemic inflammation on acute phase responses. To work effectively, IL6 must bind with its IL6 receptor (IL6R).

Objectives: The current study aimed to investigate the possible associations between two IL6R polymorphisms, namely, rs2229238 and rs4845625, and their susceptibility to T2D.

Patients and Methods: This case-control study was done on 250 T2D patients and 250 healthy individuals. The polymorphisms were genotyped using an amplification refractory mutation system-polymerase chain reaction (ARMS-PCR).

Results: Our findings showed that either the rs2229238 or the rs4845625 variant was associated with T2D in a sample of the Iranian population. The rs2229238 C/T polymorphism showed a strong significant difference in the CT genotype $(\mathrm{OR}=0.38, \% 95 \mathrm{CI}=0.23$ $0.65, \mathrm{P}=0.000)$, as well as in the TT genotype $(\mathrm{OR}=0.18, \% 95 \mathrm{CI}=0.05-0.63, \mathrm{P}=0.007)$ as a protective factor against T2D in both the patient and the control group. In contrast, the rs $4845625 \mathrm{C} / \mathrm{T}$ polymorphism showed a significant difference in the CT genotype $(\mathrm{OR}=1.92, \% 95 \mathrm{CI}=1.15-3.23, \mathrm{P}=0.031)$ and in the TT genotype $(\mathrm{OR}=1.59, \% 95 \mathrm{CI}=1.08-2.38, \mathrm{P}=0.021)$ as a risk factor for T2D in both the patient and the control group. An investigation of the alleles relating to these single nucleotide polymorphisms (SNPs) showed that the T allele of $\mathrm{rs} 2229238(\mathrm{OR}=0.34, \% 95 \mathrm{CI}=0.22-0.52, \mathrm{P}=0.000)$ and the $\mathrm{T}$ allele of $\mathrm{rs} 4845625(\mathrm{OR}=1.43, \% 95 \mathrm{CI}=1.11-1.84, \mathrm{P}=$ 0.006) were significantly different between the subject and control groups, and that these two polymorphisms play a protective and a risk factor role in T2D, respectively. A statistical analysis of the demographic and clinical data showed no significant association between the CC genotype and the CT + TT genotype: in the patient group, with the exception of body mass index $(\mathrm{BMI})(\mathrm{P}=0.023)$ in the rs4845625 polymorphism and in the control group, with the exception of HDL $(\mathrm{P}=0.025)$ in the rs2229238 SNP.

Conclusions: We identified a strong association between the T allele of IL6R gene polymorphisms (rs2229238, rs4845625) and the risk of T2D in a protective role and as a risk factor, respectively. We also found different BMI and HDL values between the patient group and the control group, respectively in compare genotypes (CT+TT vs. CC). Further studies on various ethnicities are necessary to verify our findings.
\end{abstract}

Keywords: Hyperglycemia, Inflammation, Diabetic

\section{Background}

Diabetes mellitus is one of the most prevalent chronic diseases worldwide, and it is currently on the increase in all countries (1). Specifically, the 1985 rate of 30 millions people with diabetes increased to 135 millions in 1995 and reached 173 millions in 2002. According to a WHO forecast, the diabetes rate will have risen to 366 millions worldwide by 2030 (2). According to the international diabetes fed- eration, there were approximately 4.5 million cases of diabetes in Iran in 2014, and 38,079 deaths from the disease were reported that year (3).

In mammalian species, physiological functions are facilitated by plasma levels of glucose up to $100 \mathrm{mg} / \mathrm{dL}$ (4). In general, diabetes can be divided into two types: type 1 diabetes, where people have problems producing insulin due to the destruction of the cell that produces this hormone (lack of insulin) (5) and type 2 diabetes mellitus 
(T2DM), which accounts for nearly $90 \%$ of diabetes cases worldwide (2) and is caused by insufficient production of insulin or by a malfunction of this hormone or its receptor (resistance to insulin) (5). If patients with type 2 diabetes do not control the condition, they may experience recurrent complications of diabetes, such as renal disorders (nephropathy), eye disorders (retinopathy), and nervous system problems (neuropathy) (5). These conditions can cause serious complications, including renal failure, foot injuries, amputation, and increased risk of cardiovascular diseases (6). The risk factors that give rise to the progression of T2D are mainly an increasing body mass index (BMI), aging (7), physical inactivity, stress (8), and obesity (5).

Recently, T2DM has also been recognized as an inflammatory disease in which cytokines play an important role (9). Interleukin 6 (IL6) is a proinflammatory mediator cytokine biosynthesized by T lymphocytes, macrophages, adipocytes (10), and other sources such as endothelial cells, fibroblasts, and skeletal muscle (11). IL6 is responsible for various tasks such as controlling the activation and differentiation of Tlymphocyte responses and proinflammatory responses. It also plays a role in the pathogenesis of autoimmune and inflammatory diseases (12), in the regulation of body weight, and in lipid metabolism (11).

To initiate an inflammatory response, this cytokine must bind with its receptor complex, including the Interleukin 6 receptor(IL6R)and two molecules of glycoprotein 130 (gp130) (13); the latter plays a co-receptor role (12). IL6R can occur in two forms, the first as a dimer in plasma membrane and the second in soluble form (14). Glycoprotein 130 is present in most cells, while IL6R presents in special cells like macrophages, hepatocytes, epithelial cells (10), and neutrophils (15).

Cells only have gp130 on their surfaces; for interactions with IL6, they use soluble Interleukin receptor 6 (sIL6R) (13). Generally, sIL6R is present in plasma interactions with IL6. This complex can bind to gp130 on the surface of cells without IL6R, leading to the dimerization of gp130. The above process results in signaling into cells (transsignaling) and the creation of an inflammatory state (16). The IL6R gene is located on the chromosome 1q21 (17) and includes 10 exons and nine introns. The length of this gene is $61 \mathrm{~kb}$, while the length of the mRNA transcripts from this gene is $3.3 \mathrm{~kb}(14)$.

There is little data regarding the role of IL6R polymorphisms in T2D risk.

\section{Objectives}

In this study, we tried to evaluate the possible correlation between IL6R gene polymorphisms and the risk of T2D in a sample of the Iranian population.

\section{Patients and Methods}

The participants of the study were critically selected based on levels of blood glucose after an overnight stay (fasting blood sugar). Those with levels below $100 \mathrm{mg} / \mathrm{dL}$ were placed in the healthy control group, while those with levels of $126 \mathrm{mg} / \mathrm{dL}$ were diagnosed with diabetes and placed in the case group (4). Thus, 250 outpatients with a fasting blood sugar of more than $126 \mathrm{mg} / \mathrm{dL}, \mathrm{HbA1C}>$ $6.7 \%$, and confirmed to have diabetes by a physician at the diabetes center in Zahedan were enrolled for the study. The same number of healthy controls with normal fasting blood glucose and without a family history of diabetes or specific systemic disorders were selected from the Razmjoo reference laboratory in Zahedan and enrolled for the research.

A peripheral blood sample was taken from both the patient and control groups in ethylenediamine tetraacetic acid (EDTA) tubes and the tubes were stored at $-20^{\circ} \mathrm{C}$ until extraction. To prepare the serum, tubes without anticoagulant were used to measure the lipid profiles.

All samples for the controls and subjects were extracted for genomic DNA testing using the salting-out method. The quality and quantity of the extracted DNA were confirmed using various methods such as electrophoresis, NanoDrop, and a spectrophotometer (WPA, UK) (based on a ratio of 260/280).

Demographic and clinical data were recorded for the subjects and healthy controls, including the following items: age, gender, body mass index (BMI), fasting blood sugar (FBS), total cholesterol (TC), triglycerides (TG), highdensity lipoprotein (HDL), and low-density lipoprotein (LDL). In relation to BMI, the normal range is between 18.5 and 24.9. There are three grades in terms of overweight: grade one overweight is between 25 and 29.9; grades two and three are between 30 and 39.9, and more than 40, respectively.

\subsection{Genotyping}

In the IL6R (rs2229238), C/T (NC 000014, GI 568815584), and (rs4845625), C/T (NC 000023, GI 568815575) were detected by means of an allele-specific primer-polymerase chain reaction (ASP-PCR).

The final volume of PCR amplification was $20 \mu \mathrm{L}$, which comprised $10 \mu \mathrm{L}$ of master mix (0.2 units $/ \mu \mathrm{L}$ ampliqonTaq DNA polymerase, ampliqonTaq 2x master mix, Denmark), $1 \mu \mathrm{L}(10 \mathrm{pmol} / \mathrm{mL})$ of reverse (R) and forward (F) primers, $\sim 80$ - $100 \mathrm{ng}$ of template DNA and $6.5 \mu \mathrm{L}$ of DNase-free water. 
For the single nucleotide polymorphism (SNP) rs2229238, the amplification and cycling conditions were as follows: an initial denaturation of $95^{\circ} \mathrm{C}$ for five minutes and subsequently, repeated 30 -second cycles under the following conditions: denaturation at $95^{\circ} \mathrm{C}$ for 30 seconds, annealing at $62^{\circ} \mathrm{C}$ for 30 seconds, and extension at $72^{\circ} \mathrm{C}$ for 25 seconds with a final extension at $72^{\circ} \mathrm{C}$ for five minutes.

For rs4845625, amplification was performed with an initial denaturation of $95^{\circ} \mathrm{C}$ for five minutes and subsequently, repeated 30-second cycles under the following conditions: denaturation at $95^{\circ} \mathrm{C}$ for 30 seconds, annealing at $53^{\circ} \mathrm{C}$ for 30 seconds, and extension at $68^{\circ} \mathrm{C}$ for $25 \mathrm{sec}-$ onds with a final extension at $68^{\circ} \mathrm{C}$ for five minutes. The PCR products were purified on a $1.5 \%$ agarose gel containing $0.6 \mu \mathrm{g} / \mathrm{mL}$ ethidium bromide, and observed under UV light.

Information on SNP primers is presented in Table1. The PCRs for both SNPs, namely, rs2229238 C/T and rs4845625 $\mathrm{C} / \mathrm{T}$, were performed using two sequence-specific forward primers (F1 and F2) and a common reverse primer (R) through the creation of a $319 \mathrm{bp}$ band and a $279 \mathrm{bp}$ band, respectively (Figures 1 and 2 ).

Figure 1. Electrophoresis Pattern of the Allele-Specific Primer-Polymerase Chain Reaction (ASP-PCR) for the Detection of the IL6R(rs2229238) C/T Polymorphism

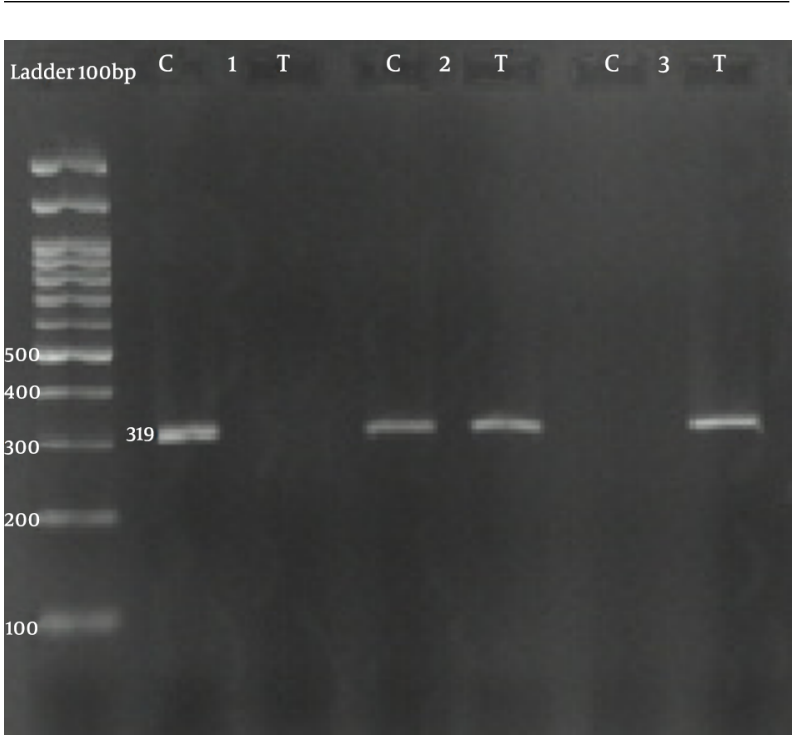

Product size, 319bp, sample 1; C, sample 2: CT, sample 3:T.

\subsection{Statistical Analysis}

SPSS software version 16.0 (SPSS Inc., Chicago, IL, USA) was used to analyze the data, and the demographic and clinical data were analyzed using the independent sample t-test and $\chi^{2}$ test.
Figure 2. Electrophoresis Pattern of the Allele-Specific Primer-Polymerase Chain Reaction (ASP-PCR) for the Detection of the IL6R (rs4845625) C/T Polymorphism

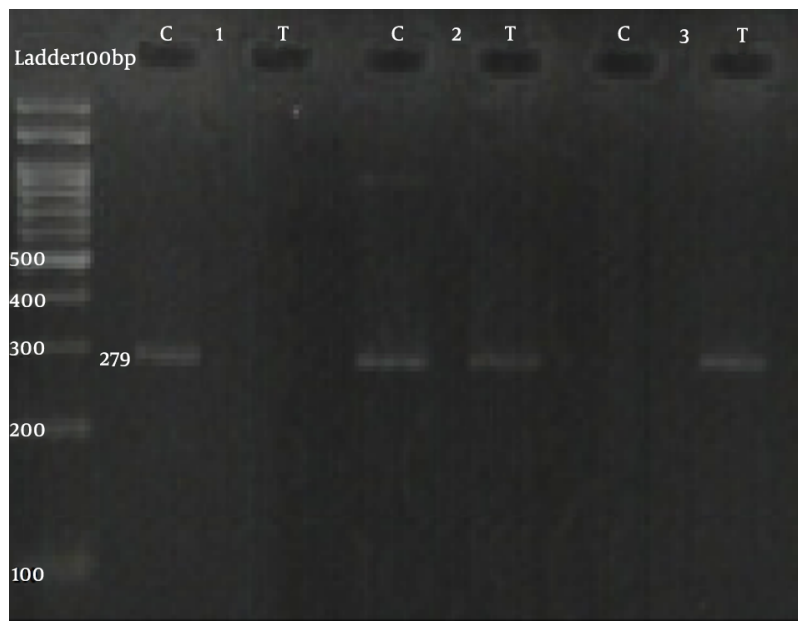

Product size: 279bp, sample 1; C, sample 2: CT, sample 3:T.

The association of the rs2229238 and the rs4845625 with T2D was assessed by computing the odds ratio (OR) and $95 \%$ confidence intervals (95\% CI) from the logistical regression analysis. In the case of all the tests, $\mathrm{P} \leq 0.05$ was considered to be significant.

\section{Results}

The study was performed on 250 Iranian diabetic patients (183 females and 67 males) with a mean age of $54.87 \pm$ 10.13 and the same number of healthy subjects ( 174 females and 76 males) with an average age of $48.85 \pm 10.01$. The demographic characteristics of the T2D patients and the controls are summarized in Table 2.

\subsection{Genotyping of ILR6 ( $r s 2229238)$}

In the $\mathrm{T} 2 \mathrm{D}$ group, the genotype frequencies in the rs2229238 polymorphism of the IL6R gene for CC, CT, and TT were $89.2 \%, 9.6 \%$, and $1.2 \%$, respectively, and in the control group, they were $73.6 \%, 20.8 \%$, and $5.6 \%$, respectively. In the evaluation of allele frequencies for the rs2229238, it was found that the $\mathrm{C}$ allele frequency was $94 \%$ and $84 \%$ in the T2D and control groups, respectively. This result showed that the CT genotype $(\mathrm{P}=0.000)$ and the TT genotype $(\mathrm{P}=$ 0.007 ) in the subject group and control group were significantly different, and that this SNP plays a protective role against T2D. By evaluating the allele, we found a significant difference between the subject and control groups. The T allele $(P=0.000)$ suggested that this SNP plays a protective role against $\mathrm{T} 2 \mathrm{D}$. 
Table 1. Allele-Specific Polymerase-Polymerase Chain Reaction (ASP-PCR) Primer Sequences

\begin{tabular}{|c|c|c|c|}
\hline Primer & Sequences (5'-3') & Product & Method \\
\hline rs2229238 & & 319 bp & ARMS \\
\hline Fw & CCTGGACCCTGTGGATGTC & & \\
\hline $\mathrm{Fm}$ & CCTGGACCCTGTGGATGTT & & \\
\hline $\mathrm{R}$ & AGCAGCTTCTCCACACCGA & & \\
\hline rs4845625 & & 279 bp & ARMS \\
\hline Fw & GGAACCAGCATACCAGTCTC & & \\
\hline $\mathrm{Fm}$ & GGAACCAGCATACCAGTCTT & & \\
\hline $\mathrm{R}$ & AGTTCTGGAGCTACCTCCTC & & \\
\hline
\end{tabular}

Table 2. Demographic Characteristics of T2D Patients and Controls

\begin{tabular}{|c|c|c|c|c|c|}
\hline \multirow[t]{2}{*}{ Characteristics } & \multicolumn{2}{|c|}{ T2D $(n=250)$} & \multicolumn{2}{|c|}{ Controls } & \multirow[t]{2}{*}{ P-Value } \\
\hline & mean $\pm S D$ & $\mathbf{N}$ & mean $\pm S D$ & $\mathbf{N}$ & \\
\hline Sex & & & & & NS \\
\hline Female & & 183 & & 174 & \\
\hline Male & & 67 & & 76 & \\
\hline FBS & $188.40 \pm 86.45$ & & $97.70 \pm 19.21$ & & $<0.0001$ \\
\hline TC & $183 \pm 44.31$ & & $181.84 \pm 36.1$ & & NS \\
\hline TG & $161.40 \pm 83.24$ & & $148.1 \pm 94.59$ & & NS \\
\hline HDL & $55.4 \pm 20.17$ & & $54.01 \pm 14.68$ & & NS \\
\hline LDL & $97.21 \pm 34.33$ & & $104.49 \pm 29.06$ & & 0.002 \\
\hline BMI & $27.63 \pm 5.49$ & & $21.48 \pm 2.43$ & & $<0.0001$ \\
\hline
\end{tabular}

Abbreviation: NS, not significant.

\subsection{Genotyping of ILR6 ( $r S 4845625)$}

In the $\mathrm{T} 2 \mathrm{D}$ group, the genotype frequencies in the rs4845625 polymorphism of the IL6R gene for CC, CT, and TT were $28.8 \%, 20.8 \%$, and $50.4 \%$, respectively, and in the control group, they were $40.4 \%, 15.2 \%$, and $44.4 \%$, respectively. In the evaluation of the allele frequencies for rs 4845625 , it was found that the $C$ allele frequency was $39.2 \%$ and $48 \%$ in the T2D and control groups, respectively. For the CT genotype $(\mathrm{OR}=1.92, \% 95 \mathrm{CI}=1.15-3.23, \mathrm{P}=0.031)$ and the TT genotype $(\mathrm{OR}=1.59$, \%95 $\mathrm{CI}=1.08-2.38, \mathrm{P}=0.021)$, there was a significant difference between the groups, indicating that this polymorphism is a risk factor for T2D. The T allele $(\mathrm{OR}=1.43, \% 95 \mathrm{CI}=1.11-1.84, \mathrm{P}=0.006)$ was also significantly higher in the T2D group. The frequencies of the allele/genotype of IL6R, including the rs2229238 C/T and the rs4845625 C/T, are shown in Table 3 for both groups. Our findings show a very significant association between the IL6R polymorphisms and T2D in our study population.

The statistical analysis presented in Table 4 regarding the demographic and clinical data demonstrates that there was no significant association between the CC genotype and the CT+TT genotype in the subject group with the exception of BMI $(\mathrm{P}=0.023)$ for the rs4845625 polymorphism and HDL $(\mathrm{P}=0.025)$ in the control group for the rs2229238 SNP.

\section{Discussion}

In this study, we investigated the possible association of the IL6R rs2229238 and rs4845625 polymorphisms with susceptibility to T2D, as well as the relationship between BMI and T2D in a sample of the Iranian population. 
Table 3. Genotypic and Allelic Frequencies of IL6R Polymorphisms in T2D Patients and Control Subjects ${ }^{\mathrm{a}}$

\begin{tabular}{|c|c|c|c|c|}
\hline IL6R Polymorphisms & Type 2 Diabetes & Control & OR $(95 \% \mathrm{CI})$ & P Value \\
\hline \multicolumn{5}{|l|}{ rs2229238 } \\
\hline $\mathrm{CC}$ & $223(89.2)$ & $184(73.6)$ & 1.00 & - \\
\hline CT & $24(9.6)$ & $52(20.8)$ & $0.38(0.23-0.65)$ & 0.000 \\
\hline TT & $3(1.2)$ & $14(5.6)$ & $0.18(0.05-0.63)$ & 0.007 \\
\hline $\mathrm{CT}+\mathrm{TT}$ & $27(10.8)$ & $66(26.4)$ & $0.34(0.21-0.55)$ & 0.000 \\
\hline $\mathrm{C}$ & $470(94)$ & $420(84)$ & 1.00 & \\
\hline $\mathrm{T}$ & $30(6)$ & $80(16)$ & $0.34(0.22-0.52)$ & 0.000 \\
\hline \multicolumn{5}{|l|}{ rs4845625 } \\
\hline $\mathrm{CC}$ & $72(28.8)$ & $101(40.4)$ & 1.00 & - \\
\hline CT & $52(20.8)$ & $38(15.2)$ & $1.92(1.15-3.23)$ & 0.031 \\
\hline TT & $126(50.4)$ & $111(44.4)$ & $1.59(1.08-2.38)$ & 0.021 \\
\hline $\mathrm{CT}+\mathrm{TT}$ & $178(71.2)$ & $149(59.6)$ & $1.68(1.15-2.43)$ & 0.007 \\
\hline $\mathrm{C}$ & $196(39.2)$ & $240(48)$ & 1.00 & \\
\hline $\mathrm{T}$ & $304(60.8)$ & $260(52)$ & $1.43(1.11-1.84)$ & 0.006 \\
\hline
\end{tabular}

${ }^{\mathrm{a}}$ Values are expressed as No. (\%).

Table 4. Association of IL6R Polymorphisms With the Clinical and Demographic Characteristics of the T2D Patients and the Control Group ${ }^{\mathrm{a}}$

\begin{tabular}{|c|c|c|c|c|c|c|c|}
\hline Genotype & Age, $y$ & Sex (male/female) & BMI, $\mathrm{Kg} / \mathrm{m}^{2}$ & TC, mg/dL & TG, mg/dL & HDL, mg/dL & LDL, mg/dL \\
\hline \multicolumn{8}{|c|}{ T2D Patients } \\
\hline \multicolumn{8}{|l|}{ rs2229238 } \\
\hline $\mathrm{CT}+\mathrm{TT}$ & $54.00 \pm 10.56$ & $6(\mathrm{M}) / 21(\mathrm{~F})$ & $28.21 \pm 4.29$ & $180.07 \pm 38.08$ & $254.52 \pm 62-47$ & $56.75 \pm 15.13$ & $91.44 \pm 28.45$ \\
\hline P-Value & 0.95 & 0.57 & 0.413 & 0.804 & 0.636 & 0.423 & 0.496 \\
\hline $\mathrm{CC}$ & $56.26 \pm 11.31$ & $22(\mathrm{M}) / 50(\mathrm{~F})$ & $28.05 \pm 7.6$ & $185.57 \pm 39.21$ & $152.75 \pm 76.83$ & $58.58 \pm 21.00$ & $95.39 \pm 29.8$ \\
\hline $\mathrm{CT}+\mathrm{TT}$ & $54.3 \pm 9.58$ & $45(\mathrm{M}) / 133(\mathrm{~F})$ & $27.58 \pm 4.27$ & $182.25 \pm 46.11$ & $164.13 \pm 85.51$ & $54.82 \pm 16.72$ & $97.09 \pm 34.94$ \\
\hline P-Value & 0.5 & 0.394 & 0.023 & 0.259 & 0.450 & 0.260 & 0.092 \\
\hline \multicolumn{8}{|c|}{ Control Group } \\
\hline \multicolumn{8}{|l|}{ rs2229238 } \\
\hline $\mathrm{CC}$ & $48.57 \pm 9.86$ & $60(\mathrm{M}) / 124(\mathrm{~F})$ & $22.24 \pm 3.12$ & $179.11 \pm 33.24$ & $145.27 \pm 86.87$ & $53.1 \pm 13.33$ & $103.37 \pm 28.49$ \\
\hline $\mathrm{CT}+\mathrm{TT}$ & $49.63 \pm 10.44$ & $16(\mathrm{M}) / 50(\mathrm{~F})$ & $22.29 \pm 2.49$ & $189.35 \pm 42.35$ & $155.94 \pm 113.9$ & $56.95 \pm 18.25$ & $107.26 \pm 31.10$ \\
\hline P-Value & 0.516 & 0.205 & 0.537 & 0.054 & 0.174 & 0.025 & 0.541 \\
\hline \multicolumn{8}{|l|}{ rs4845625 } \\
\hline $\mathrm{CC}$ & $48.94 \pm 10.46$ & $30(\mathrm{M}) / 71(\mathrm{~F})$ & $23.56 \pm 2.63$ & $178.15 \pm 32.23$ & $151.16 \pm 100.12$ & $54.21 \pm 14.50$ & $104.36 \pm 28.55$ \\
\hline $\mathrm{CT}+\mathrm{TT}$ & $48.79 \pm 9.73$ & $46(\mathrm{M}) / 103(\mathrm{~F})$ & $24.79 \pm 2.11$ & $184.46 \pm 36.60$ & $145.88 \pm 90.76$ & $53.87 \pm 14.87$ & $104.58 \pm 29.54$ \\
\hline P-Value & 0.905 & 0.844 & 0.424 & 0.182 & 0.584 & 0.266 & 0.396 \\
\hline
\end{tabular}

${ }^{\mathrm{a}}$ Data are presented as mean $\pm \mathrm{SD}$.

The results showed a significant association between the rs22229238 and the rs4845625 polymorphisms and T2D, indicating that the CT+TT genotypes of IL6R (rs2229238) decrease the risk of $\mathrm{T} 2 \mathrm{D}$ in our population by playing a protective role. In contrast, the CT+TT genotypes of IL6R (rs4845625) increase the risk of T2D. We also analyzed the association between both SNPs (rs2229238 and rs4845625) of IL6R and the demographic and clinical data; the findings showed no significant association between these variants and T2D with the exception of BMI in the case of the 
rs $4845625 \mathrm{C} / \mathrm{T}$ polymorphism in the T2D group and HDL in the case of the rs2229238 C/T polymorphism in the healthy controls.

There is little data regarding the role of IL6R polymorphisms in T2D risk. Qi et al. found, on examination, that the rs2229238 of the IL6 polymorphism may interact with C-reactive protein (CRP) in women and predict a diabetes risk (18). Conversely, the same researchers investigated this SNP in European Caucasian women and found no significant risk of $\mathrm{T} 2 \mathrm{D}$ (19).

Wolford et al. investigated the IL6R rs2229238 polymorphism in Pima Indians, recognizing the fact that rs2229238 has no significant association with sex in this population (13). Horibe et al. investigated the IL6R rs4845625 polymorphism in a Japanese study sample and found that it was significantly associated with chronic kidney disease (CKD) in this population (20).

Body mass index (BMI) is measured by dividing weight (in kilograms) by the square of the height (in meters) (21). We found an association between some variants of IL6R, such as rs4845617, and BMI and obesity in a study of a sample of Spanish women (22), although the subjects with Ala358 had a lower BMI than the homozygous ASP358 alleles in this sample of the Spanish population (23). In another study, Lin et al. investigated the IL6R rs2229238 C/T polymorphism in school children in Taiwan and found that, compared to the CC genotype, girls with the T allele had a larger waist circumference (WC) and a higher waist circumference to height ratio (WHtR) (24).

The lipid profile, consisting of very low-density lipoproteins (VLDL), low-density lipoproteins (LDL), high-density lipoproteins (HDL), total cholesterol (TC), and triglycerides (TG), was found to have a proven association with inflammatory disorders such as coronary heart disease (CHD) (25) and psoriasis (26). Diabetes is determined by an increase in fasting blood sugar (FBS) with biochemical alterations in the lipid profile (27). In a previous research study, Abe et al. examined the IL6R rs4845625 polymorphism in Japanese subjects and found that rs4845625 increased the risk of hypertriglyceridemia (28). Similarly, in scrutinizing this SNP, Chu et al. found that the rs2229238 C/T variant had a strong association with high TG (16).

In our results, no significant difference was identified between the control and case groups in terms of TG, although for HDL, there was a noteworthy difference between the genotypes in the control group. In the case of BMI, significant differences between the genotypes only arose in the T2D group, which may have been due to food culture and diet in our study population. However, the current study had some limitations, such as different ethnic groups and varying economic, dietary, and environmental conditions.

Various studies have shown that substituted nucleotides (or SNPs) in the IL6R gene cause an increase in the concentration of circulating IL6; in particular, it may lead to higher quantities of adipose tissue $(24,29)$.

In conclusion, our findings showed that the IL6R polymorphism rs2229238 is associated with T2D, and possibly plays a protective role. On the other hand, rs4845625 is a risk factor for T2D. Conversely, in a comparison of the BMI values for the rs4845625 genotypes in the patient group and HDL values for the rs2229238 genotypes in the control group, there was a significant difference between the CC and $\mathrm{CT}+\mathrm{TT}$ genotypes.

\section{Acknowledgments}

The authors wish to thank the Zahedan University of Medical Sciences, Zahedan, IR Iran, Ali Asghar hospital and everyone who participated in this study.

\section{Footnotes}

Authors' Contribution: Hamidreza Galavi and Ramin Saravani performed the data collection and laboratory work; Ramin Saravani, Ali Reza Alamdari, Nasrin Ranjbar, and Hamid Reza Galavi contributed to the study design, statistical analysis, and interpretation of the results. All of the authors read, modified, and approved the final version of the manuscript.

Funding/Support: This project was funded by the Zahedan University of Medical Sciences, Zahedan, IR Iran

\section{References}

1. Shaw JE, Sicree RA, Zimmet PZ. Global estimates of the prevalence of diabetes for 2010 and 2030. Diabetes Res Clin Pract. 2010;87(1):4-14. doi: 10.1016/j.diabres.2009.10.007. [PubMed:19896746].

2. de Almeida-Pititto B, Dias ML, de Moraes AC, Ferreira SR, Franco DR, Eliaschewitz FG. Type 2 diabetes in Brazil: epidemiology and management. Diabetes Metab Syndr Obes. 2015;8:17-28. doi: 10.2147/DMSO.S72542. [PubMed: 25609989].

3. International diabetes federation Middle East and North Africa . 2015 Available from: http://www.idf.org/membership/mena/iran.

4. Henriksen EJ, Diamond-Stanic MK, Marchionne EM. Oxidative stress and the etiology of insulin resistance and type 2 diabetes. Free Radic Biol Med. 2011;51(5):993-9. doi: 10.1016/j.freeradbiomed.2010.12.005. [PubMed: 21163347].

5. Saravani R, Esmaeeli E, Tamendani MK, Nejad MN. Oxytocin receptor gene polymorphisms in patients with diabetes. Gene, Cell Tissue. 2015;2(2).

6. Alberti K, Zimmet PZ. Definition, diagnosis and classification of diabetes mellitus and its complications. Part 1: diagnosis and classification of diabetes mellitus. Provisional report of a WHO consultation. Diabet Med. 1998;15(7):539-53. 
7. Choi BC, Shi F. Risk factors for diabetes mellitus by age and sex: results of the National Population Health Survey. Diabetologia. 2001;44(10):1221-31. doi: 10.1007/s001250100648. [PubMed: 11692170].

8. Wild S, Roglic G, Green A, Sicree R, King H. Global prevalence of diabetes: estimates for the year 2000 and projections for 2030. Diabetes Care. 2004;27(5):1047-53. [PubMed:15111519].

9. Donath MY, Shoelson SE. Type 2 diabetes as an inflammatory disease. Nat Rev Immunol. 2011;1(2):98-107. doi: 10.1038/nri2925. [PubMed: 21233852].

10. Interleukin-6 Receptor Mendelian Randomisation Analysis C, Swerdlow DI, Holmes MV, Kuchenbaecker KB, Engmann JE, Shah T, et al. The interleukin- 6 receptor as a target for prevention of coronary heart disease: a mendelian randomisation analysis. Lancet. 2012;379(9822):1214-24. doi: 10.1016/S0140-6736(12)60110-X. [PubMed: 22421340].

11. Sindhu S, Thomas R, Shihab P, Sriraman D, Behbehani K, Ahmad R. Obesity Is a Positive Modulator of IL-6R and IL-6 Expression in the Subcutaneous Adipose Tissue: Significance for Metabolic Inflammation. PLoS One. 2015;10(7):0133494. doi: 10.1371/journal.pone.0133494. [PubMed: 26200663].

12. Ferreira RC, Freitag DF, Cutler AJ, Howson JM, Rainbow DB, Smyth DJ, et al. Functional IL6R 358Ala allele impairs classical IL-6 receptor signaling and influences risk of diverse inflammatory diseases. PLoS Genet. 2013;9(4):1003444. doi: 10.1371/journal.pgen.1003444. [PubMed: 23593036].

13. De Filippo G, Rendina D, Moccia F, Rocco V, Campanozzi A. Interleukin-6, soluble interleukin-6 receptor/interleukin-6 complex and insulin resistance in obese children and adolescents. $J$ Endocrinol Invest. 2015;38(3):339-43. doi: 10.1007/s40618-014-0176-4. [PubMed: 25245339].

14. Wolford JK, Colligan PB, Gruber JD, Bogardus C. Variants in the interleukin 6 receptor gene are associated with obesity in Pima Indians. Mol Genet Metab. 2003;80(3):338-43. doi: 10.1016/j.ymgme.2003.07.003. [PubMed:14680981].

15. Chang XW, Qin Y, Jin Z, Xi TF, Yang X, Lu ZH, et al. Interleukin-6 (IL-6) mediated the increased contraction of distal colon in streptozotocininduced diabetes in rats via IL-6 receptor pathway. Int J Clin Exp Pathol. 2015;8(5):4514-24. [PubMed: 26191141].

16. Vargas VR, Bonatto SL, Macagnan FE, Feoli AM, Alho CS, Santos ND, et al. Influence of the $48867 \mathrm{~A}>\mathrm{C}$ (Asp358Ala) IL6R polymorphism on response to a lifestyle modification intervention in individuals with metabolic syndrome. Genet Mol Res. 2013;12(3):3983-91. doi: 10.4238/2013.February.28.8. [PubMed: 23479153].

17. Chu NF, Lin FH, Chin HC, Hong YJ. Association between interleukin6 receptor gene variations and atherosclerotic lipid profiles among young adolescents in Taiwan. Lipids Health Dis. 2011;10:136. doi: 10.1186/1476-511X-10-136. [PubMed: 21835044].

18. Qi L, Rifai N, Hu FB. Interleukin-6 receptor gene, plasma C-reactive protein, and diabetes risk in women. Diabetes. 2009;58(1):275-8. doi: 10.2337/db08-0968. [PubMed: 18852330].

19. Qi L, Rifai N, Hu FB. Interleukin-6 receptor gene variations, plasma interleukin-6 levels, and type 2 diabetes in U.S. Women. Diabetes. 2007;56(12):3075-81. doi: 10.2337/db07-0505. [PubMed: 17898129].

20. Horibe H, Fujimaki T, Oguri M, Kato K, Matsuoka R, Abe S, et al. Association of a polymorphism of the interleukin 6 receptor gene with chronic kidney disease in Japanese individuals. Nephrology (Carlton). 2015;20(4):273-8. doi: 10.1111/nep.12381. [PubMed: 25524550].

21. Garrouste-Orgeas M, Troche G, Azoulay E, Caubel A, de Lassence A, Cheval C, et al. Body mass index. An additional prognostic factor in ICU patients. Intensive Care Med. 2004;30(3):437-43. doi: 10.1007/s00134-003-2095-2. [PubMed: 14767583].

22. Bustamante M, Nogues X, Mellibovsky L, Agueda L, Jurado S, Caceres E, et al. Polymorphisms in the interleukin- 6 receptor gene are associated with bone mineral density and body mass index in Spanish postmenopausal women. Eur J Endocrinol. 2007;157(5):677-84. doi: 10.1530/EJE-07-0389. [PubMed: 17984249].

23. Esteve E, Villuendas G, Mallolas J, Vendrell J, Lopez-Bermejo A, Rodriguez $\mathrm{M}$, et al. Polymorphisms in the interleukin- 6 receptor gene are associated with body mass index and with characteristics of the metabolic syndrome. Clin Endocrinol (Oxf). 2006;65(1):88-91. doi: 10.1111/j.1365-2265.2006.02553.x. [PubMed:16817825].

24. Lin $\mathrm{FH}$, Chu NF, Lee $\mathrm{CH}$, Hung $\mathrm{YJ}, \mathrm{Wu}$ DM. Combined effect of C-reactive protein gene SNP $+2147 \mathrm{~A} / \mathrm{G}$ and interleukin-6 receptor gene SNP rs2229238 C/T on anthropometric characteristics among school children in Taiwan. Int J Obes (Lond). 2011;35(4):587-94. doi: 10.1038/ijo.2010.195. [PubMed: 20856253].

25. Sharrett AR, Ballantyne CM, Coady SA, Heiss G, Sorlie PD, Catellier D, et al. Coronary heart disease prediction from lipoprotein cholesterol levels, triglycerides, lipoprotein(a), apolipoproteins A-I and B, and HDL density subfractions: The Atherosclerosis Risk in Communities (ARIC) Study. Circulation. 2001;104(10):1108-13. [PubMed: 11535564].

26. Akhyani M, Ehsani AH, Robati RM, Robati AM. The lipid profile in psoriasis: a controlled study. J Eur Acad Dermatol Venereol. 2007;21(10):1330-2. doi: 10.1111/j.1468-3083.2007.02260.x. [PubMed: 17958837].

27. Rajasekaran S, Ravi K, Sivagnanam K, Subramanian S. Beneficial effects of aloe vera leaf gel extract on lipid profile status in rats with streptozotocin diabetes. Clin Exp Pharmacol Physiol. 2006;33(3):232-7. doi: 10.1111/j.1440-1681.2006.04351.x. [PubMed: 16487267].

28. Matsuoka R, Abe S, Tokoro F, Arai M, Noda T, Watanabe S, et al. Association of six genetic variants with myocardial infarction. Int J Mol Med. 2015;35(5):1451-9.

29. Harrison SC, Smith AJ, Jones GT, Swerdlow DI, Rampuri R, Bown MJ, et al. Interleukin-6 receptor pathways in abdominal aortic aneurysm. Eur Heart J. 2013;34(48):3707-16. doi: 10.1093/eurheartj/ehs354. [PubMed: 23111417]. 